\title{
O SANEAMENTO BÁSICO DE IPIAÚ E SUA INFLUÊNCIA NA QUALIDADE DAS ÁGUAS DO RIO DE CONTAS
}

\author{
Sarah Andrade Sampaio \\ Universidade do Estado da Bahia, Pós-Graduação em Estudos Territoriais \\ Salvador, BA, Brasil \\ sarahandradegeo@gmail.com \\ Ronaldo Lima Gomes \\ Universidade Estadual de Santa Cruz, Departamento de Ciências Agrárias e Ambientais \\ Ilhéus, BA, Brasil \\ rlgomes.uesc@gmail.com
}

\begin{abstract}
RESUMO
A cidade de Ipiaú se desenvolveu às margens do rio de Contas e de seus afluentes, acarretando em prejuízos à qualidade das águas destes mananciais, em virtude da carência de infraestrutura de saneamento básico, particularmente, na coleta e tratamento de esgotos domésticos. Nesse contexto, este trabalho tem o objetivo de analisar a influência do Uso e Ocupação do Solo das Áreas de Preservação Permanente (APP) do rio de Contas, relacionando com a qualidade de suas águas, assim como, espacializar as fontes geradoras de poluição hídrica por esgotamento doméstico. Para tanto, o método adotado se ampara na análise integrada de dados referentes às classes de Uso e Ocupação do Solo a partir de mapeamento de imagens de satélite; de infraestrutura de saneamento provenientes dos setores censitários do IBGE e dados pré-existentes de qualidade da água do trecho em estudo. Os resultados obtidos atestam que os setores censitários urbanos que margeiam o rio de Contas apresentam cerca de $43 \%$ de seus domicílios com descarte de seus esgotos domésticos sem tratamento adequado, numa área urbana que ocupa 73,9 ha dentro da APP no município. Tal situação de uso implica em consequências diretas e indiretas de poluição hídrica.
\end{abstract}

Palavras-chave: Poluição Hídrica. Rios Urbanos. Setores Censitários do IBGE. Área de Preservação Permanente.

\section{SANITATION CHARACTERISTICS OF IPIAÚ CITY AND ITS INFLUENCE ON THE WATER QUALITY OF RIO DE CONTAS RIVER}

\begin{abstract}
The city of Ipiaú developed on the banks of the rio de Contas and its tributaries. This fact, historically, causes damages to the water quality of these springs due to the lack of basic sanitation infrastructure, particularly the collection and treatment of domestic sewage. In this context, this paper aims to analyze the influence of Land Use and Occupation of Permanent Preservation Areas (APP) of rio de Contas, relating the quality of its waters and spatialize the sources of water pollution by domestic depletion. Therefore, the adopted method is based on the integrated analysis of data related to the Land Use and Occupation classes from satellite images mapping; of sanitation infrastructure from the IBGE census tracts and pre-existing water quality data from the section under study. The results attest to the scenario in which the urban census tracts that border rio de Contas present about $43 \%$ of their homes with their sewage disposal without proper treatment, in an urban area that occupies 73.9 ha within the APP in the municipality. Such a use situation implies direct and indirect consequences of water pollution.
\end{abstract}

Keywords: Water Pollution. Urban Rivers. IBGE Census Sectors. Permanent Preservation Área. 


\section{INTRODUÇÃO}

Os principais impactos do desenvolvimento de uma área urbana sobre as redes hidrográficas estão ligados à sua forma de ocupação, mais precisamente no que se refere à falta de infraestrutura de saneamento básico, no processo de implantação. Nesse contexto, é importante considerar o crescimento intenso de cidades brasileiras nas últimas décadas e mais recentemente, das pequenas e médias cidades. Quanto a isso, Trindade (2011, p. 72) ratifica "[...] as tendências recentes da urbanização brasileira, que apontam, entre outros fatores, para o crescimento e a importância das cidades médias".

O crescimento da população urbana está submetendo a pressões, os recursos hídricos e a capacidade de proteção ambiental de muitas cidades. Um dos problemas ao ponderar o processo de desenvolvimento urbano, resulta da expansão irregular, que em sua maioria, ocorre próximo às áreas de mananciais de abastecimento humano, comprometendo a sustentabilidade hídrica urbana (TUCCI, 2002).

Com foco na aglomeração urbana nas proximidades de canais fluviais, sabe-se que ela gera uma série de impactos, principalmente, pela grande produção de efluentes e pelo aumento do potencial a erosão e assoreamento, causado pela alteração da paisagem, a partir do uso desordenado do solo. Quanto aos problemas relacionados à poluição hídrica, destacam-se a deficiência no sistema de esgotamento sanitário, por despejo de efluentes in natura nos corpos d'água e o acúmulo de resíduos sólidos nos canais fluviais (ARAÚJO, 2003).

As mudanças fluviais induzidas pelo homem são consideradas sob dois aspectos: de forma direta, que são as modificações no canal para controlar vazões, estabilizar as margens, atenuar enchentes e inundações, minimizar a erosão ou deposição de material; e de forma indireta, no comportamento de carga e descarga sólida dos materiais em suspensão, os quais, segundo Cunha (2015), estão ligados ao uso da terra, como a remoção da vegetação, o desmatamento, a agricultura e a urbanização.

De acordo com Flinkler (2004), relacionadas às principais modificações sobre o ciclo da água no meio urbano, destacam-se as alterações: no processo de impermeabilização do solo, dada pela redução da infiltração; no aspecto da qualidade das águas, pelo aumento na geração de esgotos domésticos, a poluição gerada pelas atividades industriais e a disposição inadequada de resíduos sólidos; assim como, pelos diferentes usos do solo, uma vez que grande parte dos processos de transformação de escoamento depende do tipo de cobertura existente.

$\mathrm{Na}$ maioria das vezes, os fatores naturais, como topografia, geologia, solos, clima e vegetação, podem iniciar os desequilíbrios que serão agravados pelas atividades humanas na rede hidrográfica, especialmente pelo manejo inadequado do solo urbano e rural. "São exemplos, a substituição das matas ciliares por terras cultivadas e o avanço do processo de urbanização" (CUNHA, 2003, p. 224).

No mesmo sentido, Arcova (1999) refere-se à qualidade da água dos recursos hídricos como o resultado das seguintes interações: fatores climáticos, geológicos, pedológicos e qualidade da vegetação presente na bacia hidrográfica, independente da escala. Contanto, a compreensão das áreas modificadas por fatores antrópicos, deve ser essencial ao considerar esse aspecto. Atividades como agricultura ou ocupação urbana influenciam diretamente nas características físicas, químicas e biológicas da água.

Tendo em vista tais impactos ao meio, torna-se fundamental a conservação das Áreas de Preservação Permanente (APP), a fim de manter os recursos hídricos em boas condições. Baseadas na Lei $n^{\circ}$ 12.651/2012 (BRASIL, 2012) o tamanho mínimo da mata ciliar, que deve devidamente preservada, pode variar de acordo com a largura do rio. Tais áreas têm o objetivo principal de manter a qualidade dos cursos d'água, e sabe-se que sua retirada ou redução acarreta em consequências indesejáveis, para parte da bacia hidrográfica que é alimentada por essas águas, e para a população que nela habita.

A água é um bem natural público, logo é de todos, sendo a obrigação do Estado fornecê-la em quantidade e qualidade para todos os segmentos da sociedade. A manutenção de APPs, ao longo dos canais fluviais, é a maneira mais eficiente de garantir tais direitos (ALMEIDA; PEREIRA, 2009). Por esse motivo as APPs traduzem-se com tamanha significância, ao considerar o comprometimento da qualidade da água para fins de abastecimento. Diante das tais colocações, Martea (2002) afirma que a poluição é decorrente de diferentes fontes, tais como efluentes domésticos, industriais e deflúvio superficial urbano e agrícola. Os efluentes domésticos, por exemplo, são constituídos basicamente por contaminantes orgânicos, nutrientes e micro-organismos, que podem ser patogênicos. 
Acredita-se que essas considerações são suficientes para retratar a situação da cidade de Ipiaú-BA que, assim como muitas das cidades baianas, desenvolveu-se nas margens do rio de Contas e de seus afluente. Ipiaú tem como principal fonte hídrica para consumo humano, o rio de Contas e como rio de uso e abastecimento secundário, o rio da Água Branca, além de possuir diversos rios intermitentes.

$\mathrm{O}$ rio de Contas, que é a principal fonte de fornecimento de água para consumo humano e dessedentação animal, ocorre desde o inicio do povoamento na região, assim como a oferta de lazer e espaço para a prática desportiva chegando à fonte de alimentação e geração de emprego. O Instituto Estadual do Meio Ambiente e Recursos Hídricos (INEMA, 2018), que é o órgão gestor dos recursos hídricos no estado da Bahia, afirma que as principais demandas de água verificadas no rio de Contas são para o abastecimento humano, irrigação e geração de energia.

Este tipo de ocupação histórica acarreta prejuízos ao meio ambiente, quando não há uma adequada gestão relacionada ao saneamento básico. A fim de avaliar tais impactos, esta pesquisa tem como principais objetivos: analisar a influência do uso e ocupação do solo das Áreas de Preservação Permanente (APP) do rio de Contas, no que se refere à qualidade de suas águas; e espacializar as fontes geradoras de poluição hídrica por esgotamento doméstico, ou seja, identificar quais áreas, bairros, distritos, ou setores censitários estão contribuindo para a perda de qualidade do rio de Contas na área urbanizada do município de Ipiaú e, assim, auxiliar o poder público no que se refere à gestão hídrica municipal.

Quanto à gestão de recursos hídricos e infraestrutura de saneamento básico, de acordo com o Instituto Brasileiro de Geografia e Estatística (IBGE, 2010), o município de Ipiaú, lugar dessa pesquisa, apresenta $66 \%$ dos domicílios com esgotamento sanitário adequado. Quando comparado com os outros municípios do estado da Bahia, fica na posição $39^{\circ}$ de 417 . Já quando comparado a outros municípios do Brasil, sua posição é $1541^{\circ}$ de 5570 .

Apesar desse quadro razoável de cobertura de esgotamento sanitário no município de Ipiaú, é marcante, no perímetro urbano, a ocorrência de ocupações irregulares às margens do rio de Contas, cujo esgotamento domestico é lançado nos canais fluviais, sem nenhum tipo de tratamento, comprometendo a qualidade das águas. Para a análise socioeconômica e ambiental, a fim de auxiliar nas ações de planejamento, os dados fornecidos pelo IBGE são essenciais. Visto isso, França (2008) afirma que os setores censitários do IBGE são utilizados como principal limite político-administrativo em escala municipal para geração de informações sociais, econômicas e ambientais.

Com a finalidade de auxiliar o poder público no que se refere à falta de infraestrutura e saneamento básico, situações comuns em diversos municípios brasileiros, as quais são acarretadas por ocupações sem planejamento adequado, tais dados disponíveis devem ser utilizados para garantir um estudo aprofundado das áreas urbanas e rurais, facilitando o ações mais eficientes em nível de gestão pública.

\section{METODOLOGIA}

\section{$A$ área em estudo}

A área em estudo compreende o trecho do rio de Contas em Ipiaú-BA, entre urbano e rural, perfazendo uma faixa de $25 \mathrm{~km}$ de extensão. O município de Ipiaú dista cerca de $355 \mathrm{~km}$ da capital do Estado e localiza-se no Território de Identidade Médio rio de Contas. Possui, de acordo com o IBGE (2010), 267 $\mathrm{km}^{2}$ e população de 44.390 , sendo que 91 \% habitam áreas urbanas (Figura 1).

Segundo o INEMA (2018), a bacia hidrográfica do rio de Contas totaliza uma área de $55.483 \mathrm{~km}^{2}$, Tem seus limites geográficos ao Norte com as bacias hidrográficas do rio Paraguaçu e Recôncavo Sul, a Oeste com a bacia hidrográfica do rio São Francisco, a Leste com o Oceano Atlântico e ao Sul com as bacias hidrográficas do rio Pardo e do Leste e com o estado de Minas Gerais. O rio de Contas nasce no município de Piatã (Chapada Diamantina), desembocando no litoral do município de Itacaré, no estado da Bahia. Ao longo de sua extensão, a bacia do rio de Contas contempla cerca de 76 municípios, entre o rio principal e seus afluentes. Estima-se uma população de 1.242 .439 habitantes, toda esta população dependendo diretamente das águas do rio de Contas e seus afluentes, ocupando as terras com atividades antrópicas. 
Figura 1 - Localização do rio de Contas no município de Ipiaú-BA.

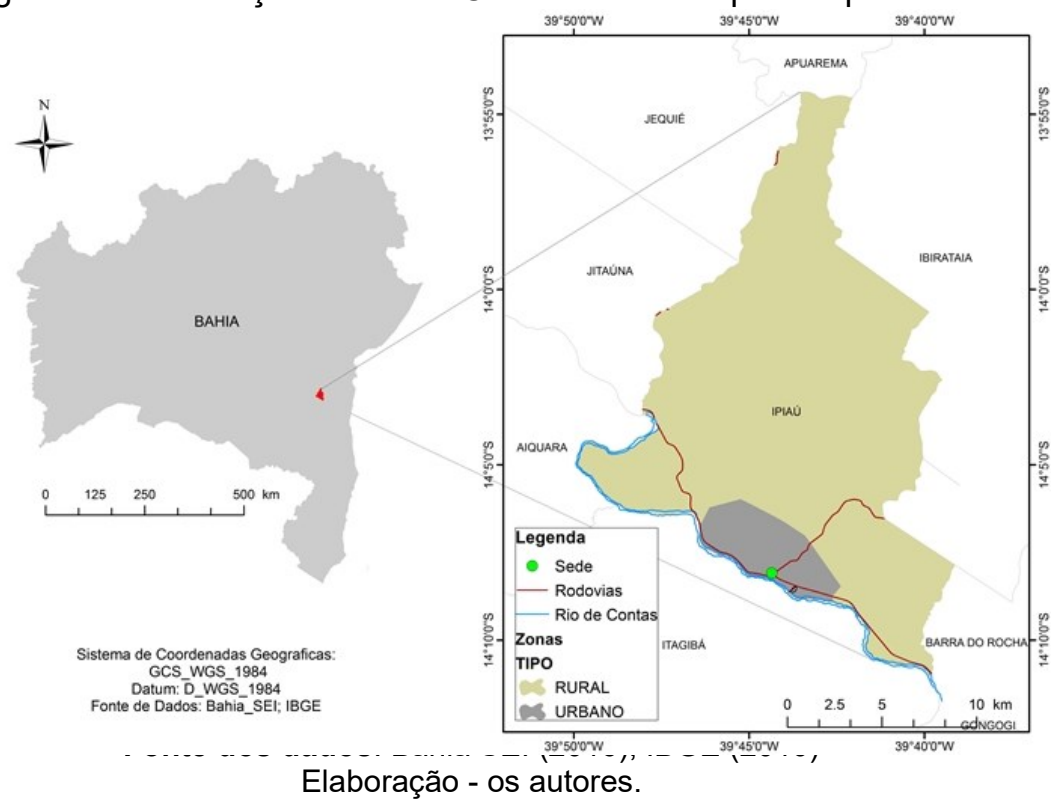

O reconhecimento dos sistemas naturais, a exemplo de aspectos pedológicos, geológicos e geomorfológicos, assim como dados climatológicos, auxilia na compreensão da estrutura e das características físico-quimicas da rede hidrográfica. Visto isso, em trabalhos de Sampaio (2019), aponta-se que os tipos de solos predominantes no município de Ipiaú, segundo dados da Comissão Executiva do Plano da Lavoura Cacaueira (CEPLAC, 2007) são Vertissolos, Latossolos e Chernossolos. A maior parte de Ipiaú é pedologicamente caracterizada por Vertissolos, presentes em toda área central e extremo norte do município, em áreas mais planas. Segundo a EMBRAPA (1999), esse tipo de solo é pouco permeável, o que restringe a sua drenagem. Tem traços mais característicos quando localizadas em áreas do município com menor pluviosidade e disponibilidade de recursos hídricos. Os Latossolos, no município de Ipiaú, estão bem distribuídos no território, são muito intemperizados e típicos de áreas com relevo mais acidentado, associados a uma elevada pluviosidade, características típicas da região Sul da Bahia. A classe de Chernossolo ocupa porção mais próxima ao rio de Contas, possui características de fertilidade bastante elevada, e tem as limitações de uso relacionadas aos riscos de erosão (EMBRAPA, 1999). Estão presentes em áreas com declividade pouco acidentadas, cuja altitude do terreno não ultrapassa $350 \mathrm{~m}$, dessa forma, seu uso no município está altamente ligado ao sistema agroflorestal de cabruca.

Quanto às características climáticas da região, definem-se em tropical úmido, influenciado pelas massas de ar úmidas vindas do Oceano Atlântico. Suas temperaturas médias e umidade do ar são elevadas durante o ano todo e as chuvas são regulares e bem distribuídas. A classificação do clima é Af, de acordo com a Köppen e Geiger, e a temperatura média no município é $23.6^{\circ} \mathrm{C}$. Tem uma pluviosidade média anual de $1200 \mathrm{~mm}$, sendo uma considerável quantidade de chuvas, bem distribuídas durante o ano, permitindo que os principais canais de drenagem sejam perenes e a vegetação esteja incluída no domínio da Mata Atlântica, na maioria do território municipal.

\section{Procedimento adotado}

O presente trabalho estruturou-se em três intenções principais: I) considerou os impactos da população residente nas margens do rio de Contas, na qualidade hídrica do rio de Contas e Água Branca, com base nos dados de saneamento básico dos setores censitários do IBGE no recenseamento de 2010, permitindo assim, uma comparação utilizando as mesmas variáveis no posterior recenseamento realizado pelo mesmo órgão, visto que é realizado a cada 10 anos; II) realizou um mapeamento das APP no trecho de $25 \mathrm{~km}$ do rio de Contas que transpassa o limite sul do município de Ipiaú, buscando inferir quais os principais impactos diretos e indiretos das atividades antrópicas nesta área; III) analisou dados de qualidade de águas disponíveis pela Agencia Nacional de Águas (ANA) e pelo INEMA nos sites oficiais, e da Empresa Baiana de Saneamento e Águas (Embasa) disponibilizados mediante solicitação oficial. Nesta pesquisa os dados numéricos e estatísticos descritivos são trabalhados assim como são consideradas as principais causas dos problemas apresentados. 
Na etapa I da pesquisa, foi feita a identificação das causas de poluição hídrica relacionadas à ocupação urbana. Foram extraídos os dados dos setores censitários do IBGE, os quais, segundo França (2008), são utilizados como principal limite político-administrativo em escala municipal para geração de informações sociais, econômicos e ambientais.

Com os dados provenientes da plataforma do Censo 2010, https://censo2010.ibge.gov.br/PA inel/?nivel=st, foram selecionados os setores censitários cujas variáveis consideram informações quanto ao destino dos resíduos sólidos (quantidade de domicílios que os descartam de maneira inadequada, jogado em rio, lago ou mar) e ao saneamento, referente ao esgotamento sanitário - se há presença de fossa séptica ou rudimentar, presença de rede geral de esgoto ou pluvial, lançamento diretamente em rio, lago ou mar ou presença de valas.

Os setores censitários cujos dados foram mais expressivos, foram relacionados aos principais bairros e localizações de referência na cidade, a fim de facilitar o entendimento e a espacialização das problemáticas ambientais. Dessa forma, dois setores censitários correspondem ao bairro Nossa Senhora Aparecida; um setor refere-se à Fábrica de Polpas de Frutas e adjacências; seis setores censitários compõem o bairro Antônio Carlos Magalhães; o Bairro Constança, e seu novo loteamento (Loteamento Constança), contabilizam dez setores censitários; há quatro setores no Centro da cidade, cujas referencias envolvem as ruas São Roque, Hildebrando Nunes e proximidades; nos bairros Dois de Dezembro e Emburrado estão oito setores censitários; as proximidades do bairro Santa Rita, Euclides Neto e Loteamento Bela Vista referem-se a cinco setores; e os setores às margens do rio de Contas, referentes às proximidades do Parque de Exposições e da Avenida São Salvador, englobando cinco, cujas observações foram mais detalhadas, devido à localização desses ser na ÁPP dos rios de Contas e Água Branca.

A etapa II consistiu no Mapeamento de Uso e Ocupação do solo na APP do rio de Contas, no trecho de $25 \mathrm{~km}$, correspondente ao município de Ipiaú, a fim de entender quais atividades antrópicas afetam diretamente a qualidade hídrica. Para tanto, foi utilizado o serviço World Imagery Basemap do ArcGIS, com imagens de alta resolução do ano de 2019. Após a análise visual da imagem, foram traçadas as margens do rio de Contas, gerando um buffer de $100 \mathrm{~m}$ do leito fluvial, seguindo a definição largura de APP de cursos d'água da Lei $n^{\circ}$ 12.651/2012 (BRASIL, 2012), e então definidas as classes de uso e ocupação do solo, executou-se a vetorização sobre tela de cada uma das classes através do módulo de edição vetorial do editor do ArcGis.

Posteriormente, para etapa III, foram adquiridos dados de qualidade hídrica disponíveis no site da ANA, do INEMA e fornecidas pela Embasa, cujos pontos coletados pelos respectivos órgãos foram localizados em um mapa, apresentado nas discussões da pesquisa. Com o objetivo de possuir parâmetros de comparação e complementação das informações, a ANA dispõe na plataforma HIDROWEB do Sistema Nacional de Informações sobre Recursos Hídricos (SNIRH), coletadas pela Rede Hidrometeorológica Nacional (RHN), dados de níveis fluviais, vazões, chuvas, climatologia, qualidade da água e sedimentos, entre outros fatores, no endereço eletrônico http://www.snirh.gov.br/hidroweb/publico/medicoes_historicas_abas.jsf. Neste trabalho, foram considerados os dois pontos (identificados como pontos 1 e 2), com os valores médios dos parâmetros de Qualidade da Água disponibilizados pelo órgão, no trecho do rio de Contas inserido no município de Ipiaú, com os respectivos parâmetros: Potencial Hidrogeniônico $(\mathrm{pH})$, condutividade elétrica, Demanda Química de Oxigênio (DQO), turbidez, e Oxigênio Dissolvido (OD), apresentados em uma tabela.

A análise do INEMA refere-se ao nível de eutrofização no trecho do rio de Contas, comprovados por coletas realizadas a cada três meses pelo instituto, durante um período de cinco anos (2013 a 2017). Tais dados estão disponibilizados em gráficos na plataforma MONITORAMENTO (SEIRH), no endereço eletrônico http://monitoramento.seia.ba.gov.br/ paginas/qualidadeagua/graficos/iet/. Foram considerados parâmetros físicos, químicos e biológicos, compondo o Índice de Estado Trófico do canal fluvial, cujas informações estão apresentadas em um gráfico nos resultados e discussões desta pesquisa.

Os dados de qualidade hídrica foram fornecidos pela Embasa mediante solicitação oficial, e entregue em mãos, na unidade regional de Jequié-BA. O Relatório de Monitoramento Ambiental, com levantamentos mensais no ano de 2017, apresenta informações mais completas para esta pesquisa, condizentes aos dados de fatores físico-quimicos e biológicos, tais como $\mathrm{pH}$, presença ou ausência de materiais flutuantes, Sólidos Totais Dissolvidos ( $\mathrm{mg} / \mathrm{L}), \mathrm{DBO}(\mathrm{mg} / \mathrm{L}), \mathrm{DQO}(\mathrm{mg} / \mathrm{L})$, temperatura da água $\left({ }^{\circ} \mathrm{C}\right)$, turbidez (NTU), coliformes totais (NMP) e E. Coli (NMP). Tais coletas foram realizadas pela empresa em dois pontos, com o objetivo de aferir a qualidade do efluente após passar pela estação de

$\begin{array}{lllll}\text { Caminhos de Geografia } & \text { Uberlândia-MG } & \text { v. 21, n. } 74 & \text { Abr/2020 } & \text { p. 68-86 }\end{array}$


tratamento de esgoto (ETE), e lançado no rio de Contas: 1) a montante do corpo receptor (97 metros antes do lançamento do efluente tratado pela empresa $-14^{\circ} 10^{\prime} 58.2^{\prime \prime S} 39^{\circ} 39^{\prime} 53.42^{\prime \prime}$ W) e 2) à jusante

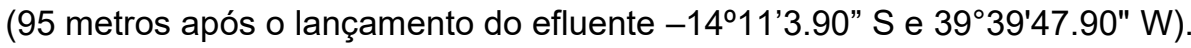

Por fim, foram comparados os dados de infraestrutura de saneamento básico obtidos dos setores censitários urbanos adjacentes aos rios de Contas e Água Branca, os dados de cobertura de Uso e Ocupação de APP do rio de contas e os dados secundários de qualidade da água no trecho do rio de Contas que transpassa o limite sul do município de Ipiaú, e apontadas causas e consequências dos impactos ambientais ao canal fluvial em questão.

\section{RESULTADOS E DISCUSSÃO}

\section{CARACTERÍSTICAS DO SANEAMENTO BÁSICO NOS SETORES CENSITÁRIOS DO IBGE (2010), EM IPIAÚ}

As análises relacionadas aos dados dos setores censitários, conforme as variáveis escolhidas nesta pesquisa, correspondem à contribuição dos domicílios do município para a poluição hídrica em atividades diretas, com análise focada na área urbana (Figura 3). O município tem um número aproximado de 13.000 domicílios (entre casas, casas de vila ou em condomínio e apartamentos). Para cada um desses domicílios foram traçadas as características de habitação, renda, populacional, entre outras, através de entrevista presencial, realizada pelo IBGE no recenseamento de 2010.

Figura 3 - Localização dos setores censitários no município de Ipiaú-BA.

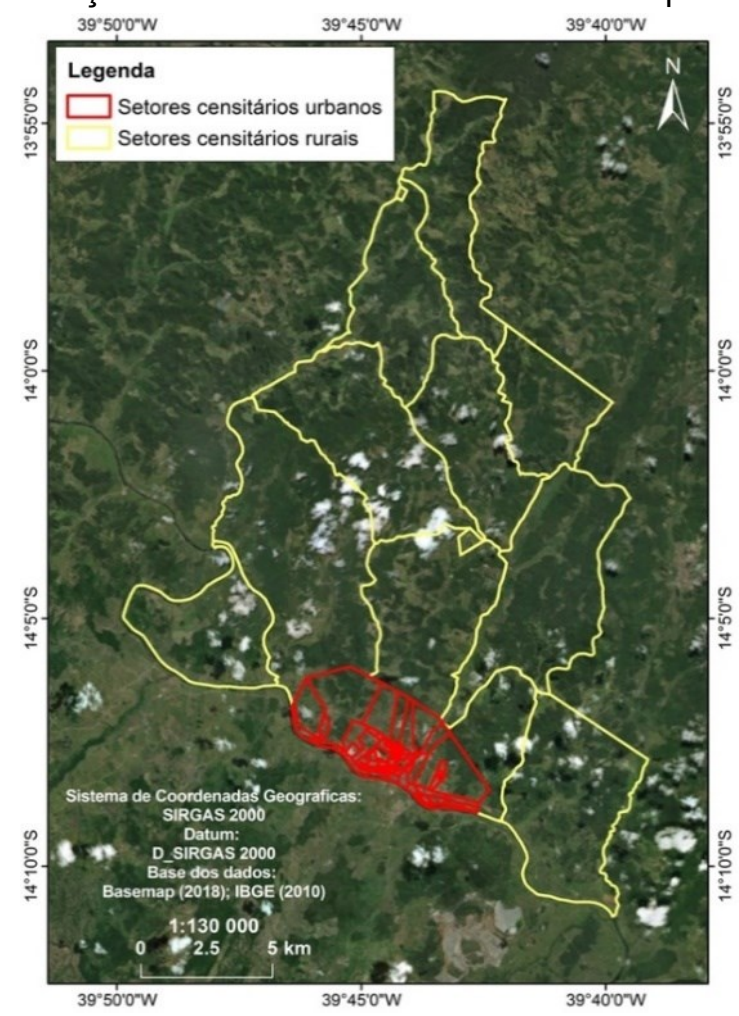

A partir dos dados dos setores censitários, disponíveis na plataforma do Censo 2010 do IBGE, foram selecionadas para a análise, as variáveis de saneamento básico. Nesse sentido, as Figuras $4 \mathrm{a}, 4 \mathrm{~b}, 4 \mathrm{c}$, $4 \mathrm{~d}, 4 \mathrm{e}$ e $4 \mathrm{f}$ sintetizam informações quanto ao destino dos resíduos sólidos (quantidade de domicílios que o descarta de maneira inadequada, jogado em rio, lago ou mar) e quanto ao saneamento, referente ao esgotamento sanitário - se há presença de fossa séptica ou rudimentar, presença de rede geral de esgoto ou pluvial, lançamento diretamente em rio, lago ou mar ou presença de valas. 
Figura 4 - Quantidade de domicílios, em Ipiaú-BA, com relação ao tipo de esgotamento sanitário, segundo análise dos setores censitários do IBGE (2010).
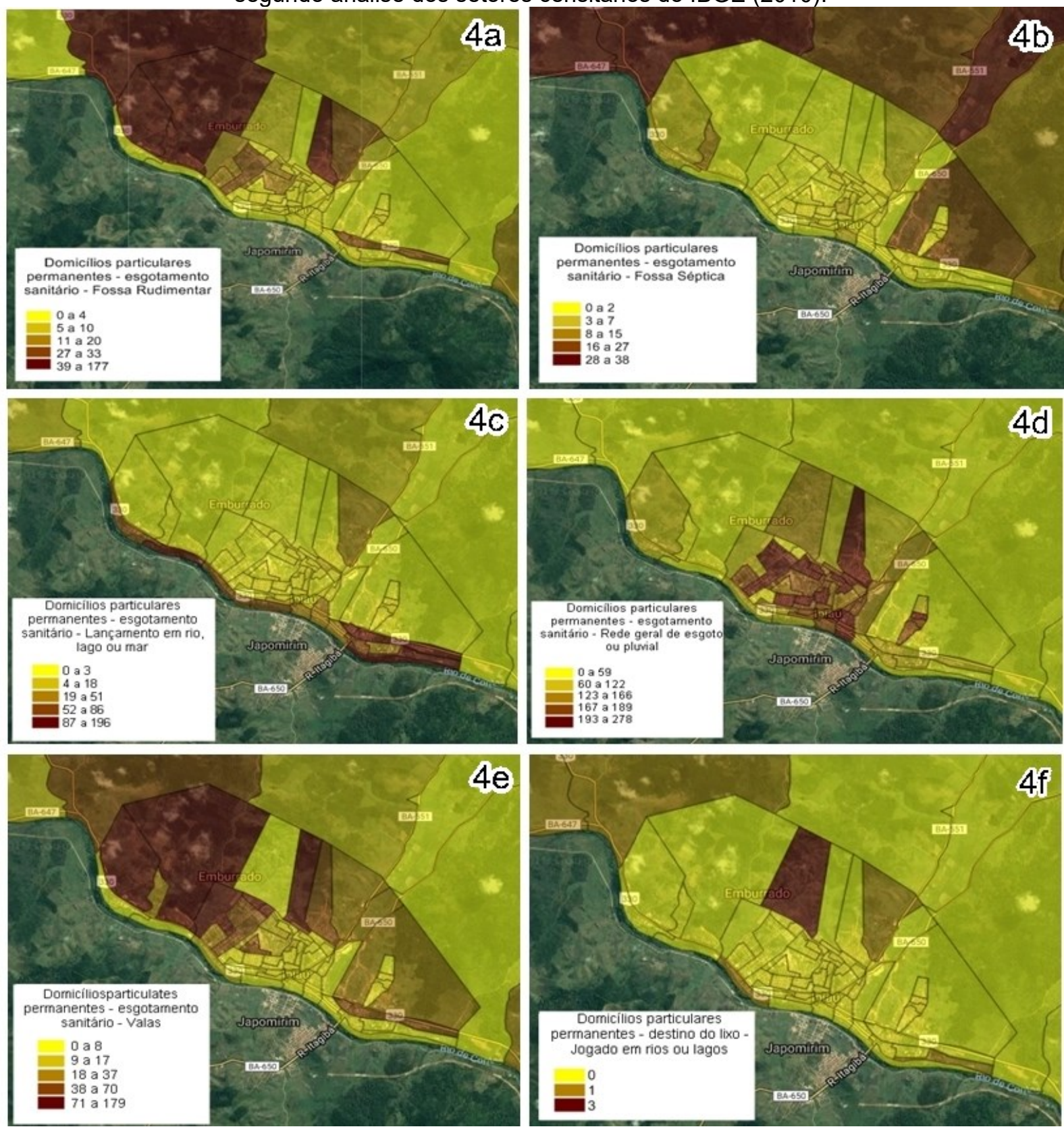

Fonte - Censo 2010, IBGE

De acordo com a Figura $4 a$, referente à quantidade de domicílios que possuíam sistema de fossa rudimentar na área estudada, destacam-se os seguintes setores: o setor nas proximidades do Parque de Exposições (31 domicílios, ou seja, 10,2 \% destes); o setor em que está inserido o Loteamento Bela Vista (45, contabilizando $10,2 \%$ dos domicílios) e seu setor adjacente (32, contabilizando $34,4 \%$ dos domicílios); o setor próximo ao Hospital Geral de Ipiaú (27 domicílios, ou seja, 9,1 \% destes); o setor junto ao bairro Nossa Senhora Aparecida, que é menos urbanizado (177, contabilizando $57,8 \%$ dos domicílios); e o setor onde está inserida a Fábrica de Polpas de Frutas (57, contabilizando $32,6 \%$ dos domicílios). Ressalta-se que o tratamento de esgotos domésticos por fossas rudimentares, dispositivo destinado à disposição do esgoto no solo, que permite infiltração de líquidos sem que haja separação da parte sólida. Este tipo de estrutura é comum em áreas rurais, e possui menor eficiência, já que este tipo de sistema de tratamento não funciona como forma de evitar a contaminação das águas superficiais e subterrâneas. As fossas rudimentares destinam-se a receber, acumular e dispor no solo o esgotamento doméstico e comumente caracterizam-se como sumidouros onde não foram implantadas as fossas sépticas à montante. 
Fossas sépticas são mais eficientes que as fossas rudimentares, pois elas retêm a parte sólida e iniciam o processo de purificação da parte líquida, a qual é concluída através da filtração no solo (EMBRAPA, 2018), e não é lançada diretamente na superfície das águas. Assim como a fossa rudimentar, tal sistema de tratamento também é indicado para uso em ambientes rurais, já que devido aos usos e ocupações no meio urbano não há espaço disponível para tal estrutura. Relacionados à Figura 4b, sobre a quantidade de domicílios que possuíam sistema de esgoto com fossa séptica, destacam-se: o setor circunvizinho do bairro Antônio Carlos Magalhães (21 domicílios, contabilizando 31,8 \%); o setor onde se localiza o Bairro Nossa senhora Aparecida, próximo à Estação de Tratamento de Água (8, contabilizando $8,2 \%$ dos domicílios); e os setores censitários mais urbanos, no bairro Constança, nas proximidades da Travessa Carlos Chagas (6, contabilizando 2,3\% dos domicílios) e a rua Alfredo Brito, nas margens do rio de Contas (5, contabilizando $2,2 \%$ dos domicílios).

Correspondente à Figura $4 \mathrm{c}$, com a quantidade de domicílios cujo esgotamento sanitário é lançado diretamente nos rios de Contas e Água Branca ou em lagos, destacam-se: o setor censitário adjacente ao Loteamento Bela Vista (19, ou seja, 9,8 \% dos domicílios); e todos os setores da área urbanizada que estão nas margens do rio de Contas, com números expressivos de despejo do esgoto doméstico sem tratamento: o setor censitário que envolve o bairro mais afastado do centro, nas proximidades da Fábrica de Polpas de Frutas (60, ou seja, 33,8 \% dos domicílios); o setor que envolve os novos loteamentos, também nas margens da cidade (87, ou seja, $62,1 \%$ dos domicílios); o setor que envolve o bairro Dois de Dezembro (85, ou seja, $43,8 \%$ dos domicílios); os 4 setores censitários que envolvem o Centro da cidade (apresentam 57, 27, 47 e 47 domicílios, respectivamente, ou seja, 34,9, 12,1, 17,9 e $39,8 \%$ destes); mais próximo dos limites a leste da cidade, estão os setores mais expressivos: o que envolve o Parque de Exposições (196, ou seja, $100 \%$ dos domicílios), no setor que está inserida a Avenida São Salvador (177, ou seja, $83,8 \%$ dos domicílios), onde situa-se a Rua São Roque (96, ou seja, 31,6\% dos domicílios), e no setor correspondente à rua Hildebrando Nunes (52, ou seja, $25 \%$ dos domicílios do setor), pelos quais o rio Água Branca perpassa.

$\mathrm{Na}$ Figura 4d, que considera o esgotamento sanitário com presença de rede geral de esgoto ou pluvial - serviço prestado pela Embasa, o destaque é dado para os setores censitários que apresentam os menores valores, já que há a falta de intraestrutura relacionada ao saneamento. No setor onde se insere o loteamento próximo a rua Nossa Senhora Aparecida (11, ou seja, apenas 3,5\% dos domicílios possuem esse serviço); no setor onde se insere parte do bairro Aloísio Conrado (9, ou seja, $6,4 \%$ dos domicílios); os 2 setores censitários nas proximidades do bairro Euclides Neto (92 e 93 respectivamente, ou seja, 28,1 e 16,1\% domicílios); no centro da cidade, destacam-se os setores onde se localiza o Banco do Brasil (71, ou seja, $60,1 \%$ dos domićílios possuem o serviço), e na Avenida São Salvador (23, contabilizando 10,9\% dos domicílios); nos setores adjacentes a estes, onde se insere o Parque de Exposições (apenas 2, ou seja, $1 \%$ dos domicílios possuem esse serviço) e no setor circunvizinho do bairro Antônio Carlos Magalhães (11, ou seja, 16,6 \% dos domicílios). Ou seja, os setores censitários que estão mais próximos dos rios de Contas e Água Branca possuem a menor quantidade de domicílios com infraestrutura básica de saneamento de esgoto, despejando assim os dejetos diretamente nesses rios.

A presença de valas - destinação também inadequada para efluentes domésticos - tem números menos expressivos na cidade (Figura 4e). Os setores que se destacam são os mais distantes do centro da cidade de Ipiaú, como nas proximidades do bairro Emburrado ( 3 setores totalizam 349 domicílios, ou seja, $43,3 \%$ ), no setores nas proximidades do Loteamento Bela Vista (111, ou seja, $39 \%$ domicílios), 2 setores que compõem parte do bairro Euclides Neto (280, contabilizando 67,4 \% dos domicílios), parte do Loteamento Constância (51, ou seja, $26,4 \%$ dos domicílios) e o setor próximo ao Parque de Exposições (40, ou seja, 13,2 \% dos domicílios).

$\mathrm{Na}$ Figura 4f, que apresenta dados sobre o destino dos resíduos sólidos que são descartados inadequadamente em corpos hídricos, evidenciam-se dois setores censitários na área de estudo: um próximo ao bairro Emburrado ( 3 , ou seja, 1,7 \% dos domicílios), outro no centro da cidade, às margens do rio de Contas (com apenas 0,5\% dos domicílios, ou seja, 1 domicílio).

Referente às informações de abastecimento de água, destino de resíduo sólido e esgotamento sanitário em escala municipal, ainda na plataforma do Censo 2010 do IBGE, considera-se os dados quanto ao

$\begin{array}{lllll}\text { Caminhos de Geografia } \quad \text { Uberlândia-MG } & \text { v. 21, n. } 74 \quad \text { Abr/2020 } & \text { p. 68-86 } & \text { Página } 75\end{array}$ 
abastecimento de água, os quais apontam que $89,9 \%$ possuem rede geral de abastecimento, $4 \%$ apresentam poço ou nascente nas propriedades, 0,1\% utilizam a água de chuva armazenada em cisternas, 6,4 \% têm outras formas de abastecimento.

Referente aos dados sobre o destino de resíduos sólidos no município de Ipiaú, a porcentagem desses, coletados por serviço de limpeza municipal é 91,3\%. Além disso, $7 \%$ dos resíduos sólidos são queimados, $0,2 \%$ são enterrados nas propriedades, $1,6 \%$ são jogados em terrenos baldios ou logradouros, $0,06 \%$ são jogados diretamente em rio ou lago, 0,2 \% dos resíduos sólidos possuem outro destino.

Acerca dos indicativos de esgotamento sanitário no município, tem-se apenas $1,8 \%$ do esgotamento com presença de fossa séptica, $6,4 \%$ possuem fossa rudimentar, $66,5 \%$ contêm uma rede geral de esgoto ou pluvial de serviço público, 9,3\% dos domicílios no município lançam seus efluentes diretamente em rios, lagos ou mar, $11,9 \%$ contam com a presença de valas, e 4 \% têm outras formas de esgotamento.

Nesse sentido, observa-se que no ano de 2010, quando foi realizado o recenseamento, a infraestrutura municipal referente à distribuição de água e coleta e tratamento de esgotos domésticos era deficiente, com vistas ao centro da cidade, nas proximidades dos canais fluviais, assim como em áreas mais periféricas, próximas aos novos bairros que surgiram na ultima década.

\section{Mapeamento do uso do solo incluso na APP do rio de Contas em Ipiaú}

A Lei $n^{0} 12.651 / 12$ do atual Código Florestal traduz as funções de uma APP, elencando entre outros fatores, a preservação os recursos hídricos, a estabilidade das paisagens, a biodiversidade e proteção do solo (BRASIL, 2012). A origem de Ipiaú se deu na APP do canal principal, às margens do rio de Contas e expandiu-se, assim como o desenvolvimento de atividades antrópicas com os mais diferentes usos e ocupações em toda área. A fim de compreender quais atividades se dão na referida área, foi realizada uma vetorização (ver Figuras $5 a, 5 b$ e $5 c$ ) apontando os principais usos, e apresentadas as classes encontradas.

Figuras $5 a, 5 b$ e $5 c$ - Uso e ocupação do solo da APP do rio de Contas no município de Ipiaú-BA.

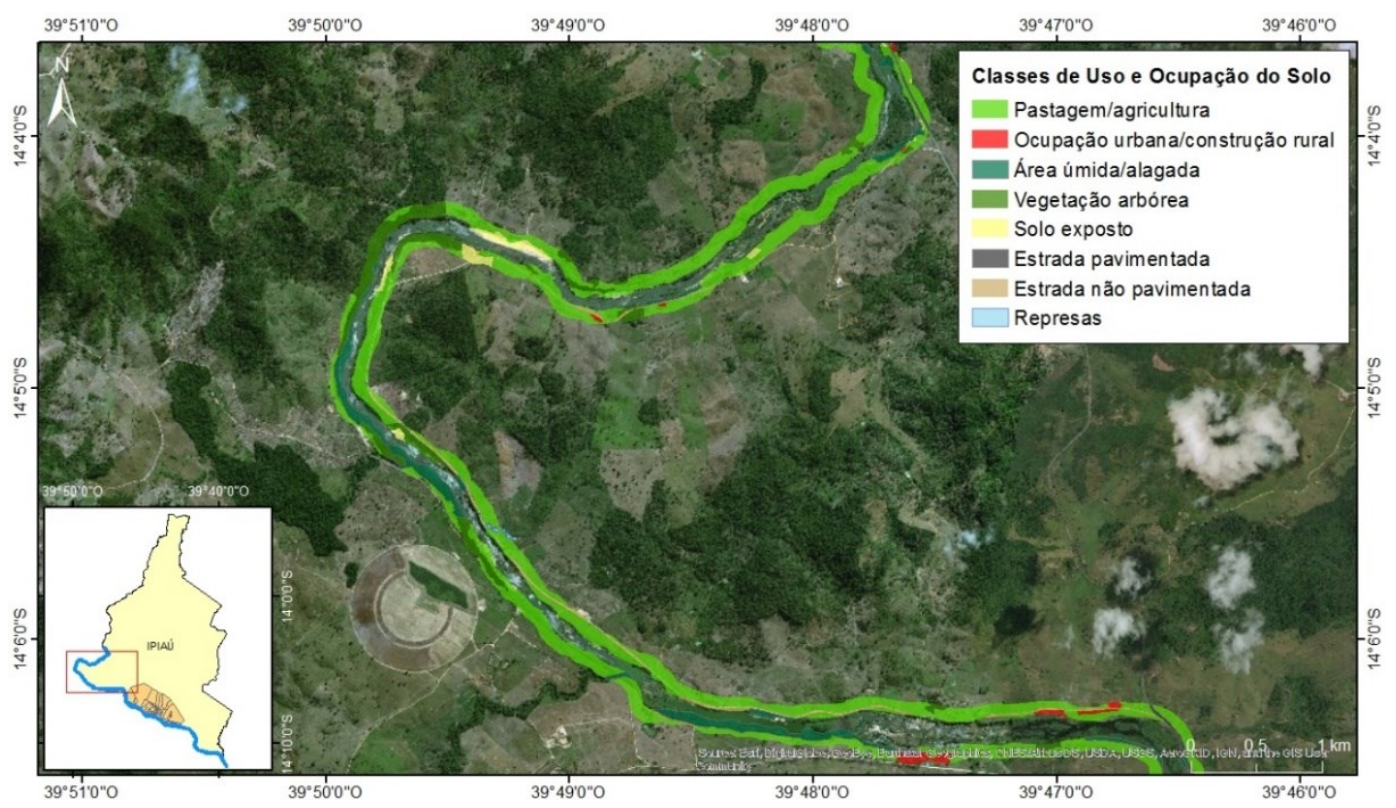



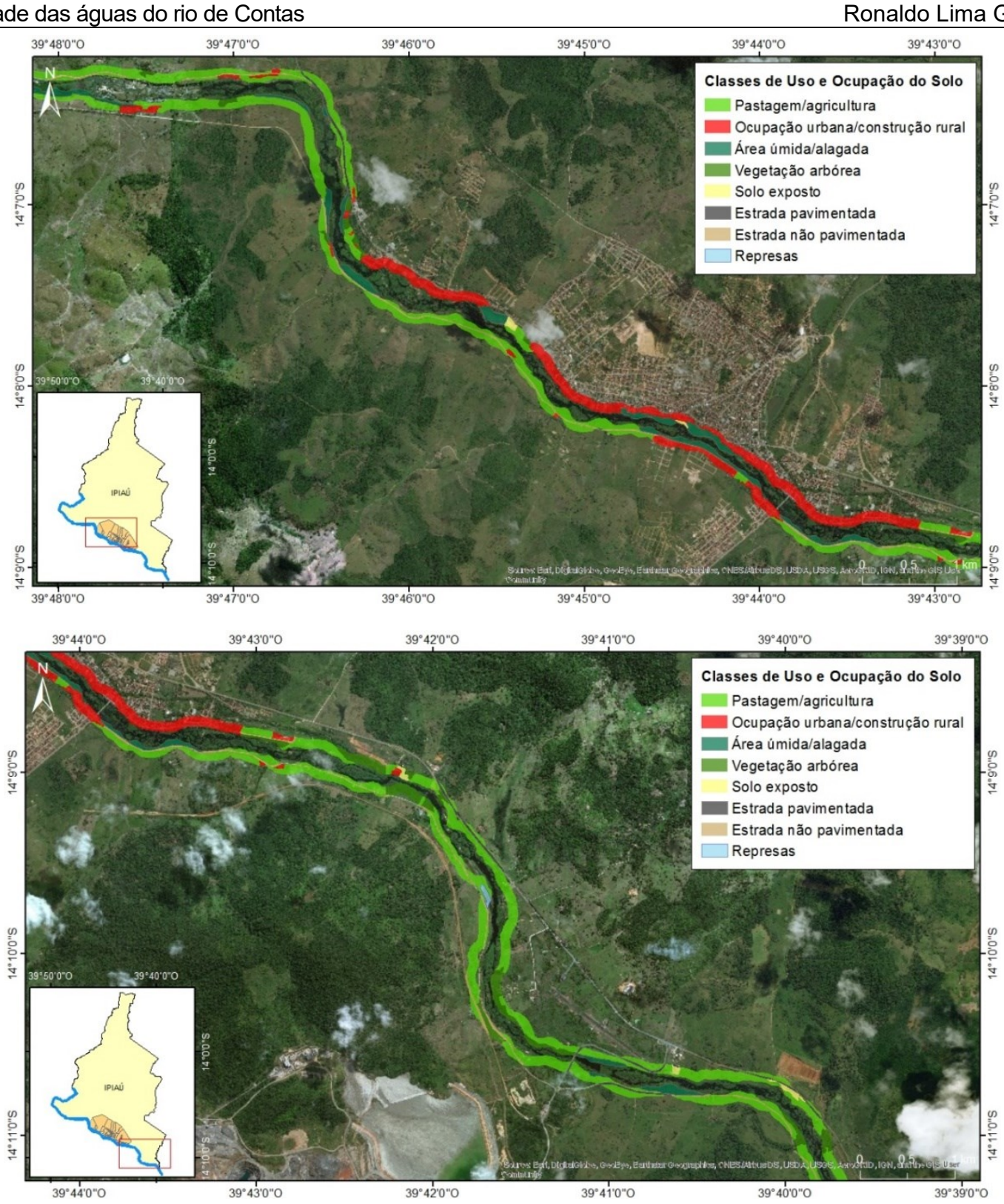

Fonte - Imagens Basemap (2018). Elaboração - os autores.

Nesse sentido, com o objetivo de quantificar tais classes, a Tabela 1 apresenta os usos e suas respectivas áreas ocupadas.

Tabela 1 - Classes de uso e ocupação do solo em área de APP do rio de Contas em Ipiaú-BA, 2018.

\begin{tabular}{lcc}
\hline \multicolumn{1}{c}{ CLASSES } & ha & ÁREA OCUPADA \\
\hline Pastagem/agricultura & 406,3 & $\%$ \\
Ocupação urbana/construção rural & 73,9 & 62,1 \\
Área úmida/alagada & 61,7 & 11,3 \\
Vegetação arbórea & 60,0 & 9,5 \\
Solo exposto & 11,5 & 9,2 \\
Estrada pavimentada & 10,3 & 1,8 \\
Estrada não pavimentada & 28,3 & 1,5 \\
Represas & 1,4 & 4,4 \\
\hline TOTAL & 653,4 & 0,2 \\
\hline
\end{tabular}

Fonte - dados da pesquisa, 2018. 
Conforme dados dispostos na Tabela 1, considerando as atividades de pastagem e agricultura como principais usos do solo na APP do rio de Contas (62,1 \% do total), que são áreas com vegetação rasteira, geralmente em propriedades rurais, percebe-se o impacto dos usos e possíveis alterações no fluxo do rio, já que tais áreas deixam o solo parcialmente exposto, sujeitos a ações erosivas, diminuição do conteúdo de carbono nos solos (IBGE, 2006).

A classe de ocupação urbana/construção rural (11,3\%), disposta na Tabela 1, é referente a áreas de uso intensivo, contínuas e não contínuas, em construções consolidadas na cidade ou em propriedades rurais. Tal uso causa impactos significativos, segundo Santos, Rufino e Filho (2017, p. 944):

I) a sobrecarga no sistema de drenagem urbana por meio do aumento da impermeabilização do solo e da diminuição da infiltração; II) a perda da cobertura vegetal por pavimentos impermeáveis, diminuindo a infiltração da água no solo e aumentando a sua quantidade e a sua velocidade de escoamento; III) a escassez e a diminuição da qualidade dos recursos hídricos; IV) o acúmulo de resíduos sólidos nos elementos do sistema de drenagem (canais, bueiros, bocas de lobo, etc.), obstruindoos e, com isso, ocasionando seus transbordamentos em períodos de chuva; e V) o aumento da densidade urbana em determinadas zonas, principalmente as consideradas de baixo valor especulativo imobiliário da cidade (SANTOS, RUFINO e FILHO, 2017, p. 944)

As áreas úmidas/alagadas (representando $9,4 \%$ da área mapeada, na Tabela 1) correspondem a delimitações adjacentes ao curso fluvial sujeitas a alagamentos recorrentes ou que possuam superfície úmida com desenvolvimento da flora aquática. Por ser área de vegetação natural, não acarretam tantos prejuízos ao ecossistema quando comparada às classes anteriores. Em contrapartida, a grande concentração dessa flora, em maioria, baronesas (Eichornia crassipes), bioindicadores de poluição ambiental, aumenta a taxa de oxigênio disponível na água, sendo capaz de impedir a proliferação de algas benéficas e causando a morte de organismos aquáticos, como os peixes (PINHO, 2001).

A cobertura do solo por vegetação arbórea corresponde a árvores de grande médio a grande porte com espécies variadas. Esse tipo de vegetação protege o solo do impacto de chuvas, diminuindo a probabilidade de erosão, sendo o tipo de cobertura que permite o ideal funcionamento ecológico em APPs, reduz a velocidade de escoamento superficial e favorece a infiltração de água no solo. Na área mapeada, elencada na Tabela 1, apenas 9,1 \% são cobertos por árvores.

O que foi identificado como solo exposto (na Tabela 1, 1,7 \% da área) abrange áreas de novos loteamentos, bancos de areia não alagados junto ao rio, áreas com retirada completa de vegetação para atividades agrícolas ou ambientes de erosão. São áreas de intensa fragilidade, para as quais deve ser dada a devida atenção. Este tipo de uso do solo envolve diversos malefícios ao curso do rio, já que aumenta significativamente a quantidade de sedimentos em suspensão e em transporte, consequentemente, a turbidez da água.

Correspondente à classe de estradas pavimentada (1,5\% da área na Tabela 1$)$, identificaram-se rodovias federais e estaduais que perpassam as APPs do rio de Contas, como a BR330 e BA650. Neste tipo de uso, os principais problemas estão relacionados com a compactação do solo, impedindo a infiltração hídrica assim como o transporte de sedimentos menores por ação pluvial para o nível do canal.

Dispostas na Tabela 1, as estradas não pavimentadas têm maior porcentagem na área (4,3\%), ao comparar-se com o total de estradas pavimentadas, e correspondem a estradas rurais com alta susceptibilidade à erosão, cuja cobertura é cascalho, argila e areia, com materiais não consolidados, facilmente transportados.

A classe de uso e ocupação do solo na APP do rio de Contas identificada como represas (pautada na Tabela 1 com $0,2 \%$ da área) é ambiente de pequeno porte alagado por ação antrópica, que está em ambientes rurais. Na visualização por imagens de satélite, tais áreas estão com elevado nível de eutrofização (confirmado pela existência de flora aquática na superfície). 


\section{Características da qualidade da água do rio de Contas, em consequência da ocupação urbana de Ipiaú-BA}

A Figura 6 apresenta a localização dos pontos de análise hídrica da ANA, do INEMA e da Embasa. A análise do INEMA refere-se ao nível de eutrofização no trecho do rio de Contas durante um período de cinco anos (2013 a 2017). As análises da ANA e da Embasa apresentam valores referentes à qualidade hídrica nos pontos de coleta, os quais permitem inferir sobre a contribuição do centro urbano referente à condição do esgoto doméstico lançado no rio de Contas.

Figura 6 - Localização dos pontos de análise hídrica pela ANA, pelo INEMA e pela Embasa no trecho do rio de Contas em Ipiaú-BA, 2017.

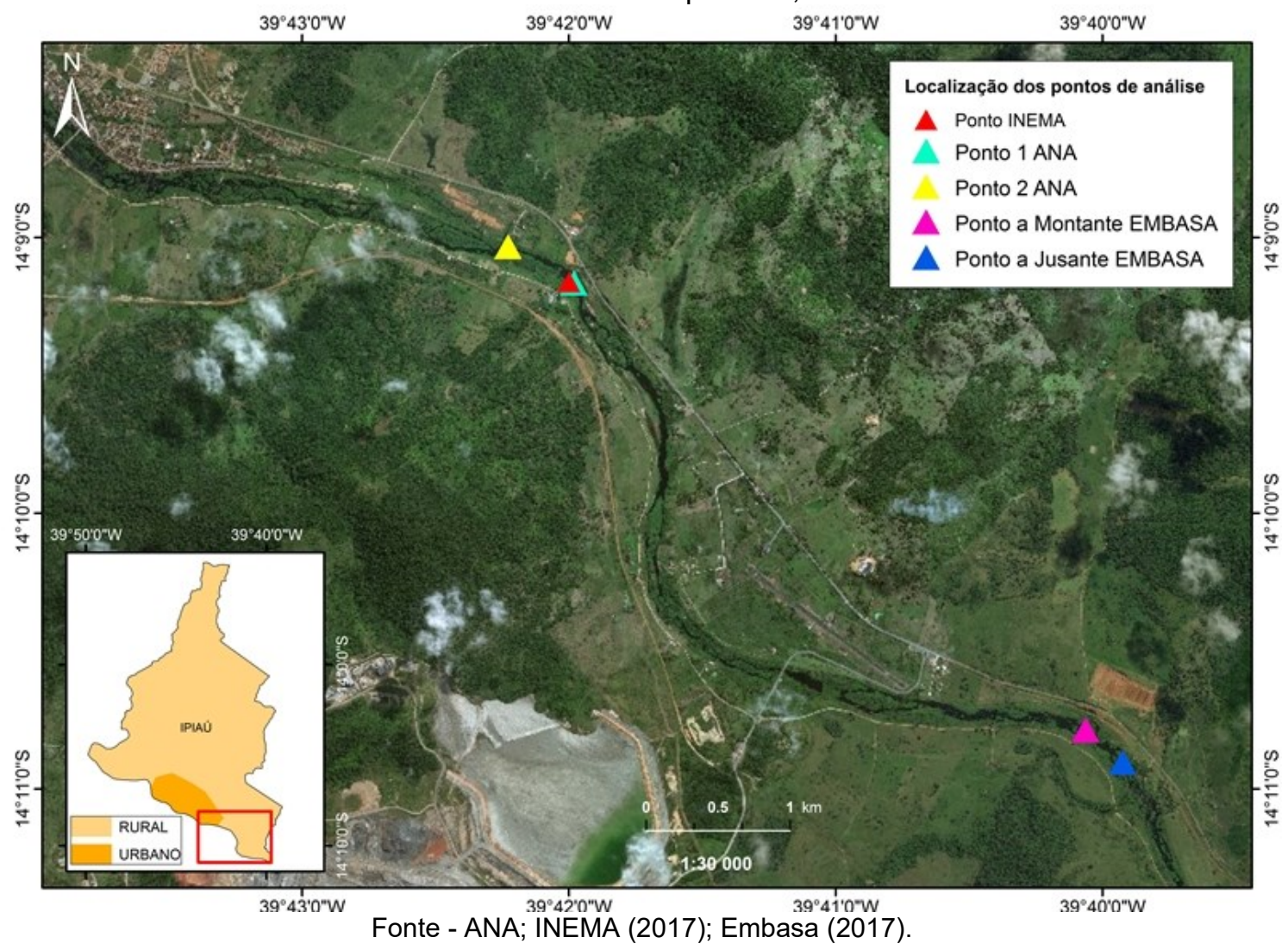

Com relação ao ponto de análise do INEMA, cujo local de coleta é coincidente ao ponto 1 de medição da ANA (ver Figura 6, o mapa de localização dos pontos), tem como objetivo monitorar o Índice de Estado Trófico do ponto de análise. Os resultados encontrados encontram-se apresentados na Figura 7.

Conforme indica a Figura 7, a qual trata dos valores do Índice de Estado Trófico (IET), as classificações são feitas pelo INEMA conforme o nível de eutrofização, que segundo Valente et al (1997) é o aumento da concentração de nutrientes, especialmente fósforo e nitrogênio, nos ecossistemas aquáticos, que tem como consequência a ampliação de suas produtividades. Inversamente ao processo natural de eutrofização dos corpos hídricos, nos quais os ambientes passam paulatinamente pelas condições oligotrófica - mesotrófica - eutrófica, quando a atuação antrópica é direta acelera-se o processo para anos ou décadas, relacionado diretamente com a contribuição de esgotos sem tratamento adequado aos canais fluviais. A Figura 7, com o IET do ponto de análise pelo INEMA apresenta classificações em diferentes anos do mesmo ponto de coleta, atingindo níveis até supertróficos, no ano de 2016, indicando elevados níveis de poluição. 
Figura 7 - IET do ponto de análise pelo INEMA, Ipiaú-BA, 2017.

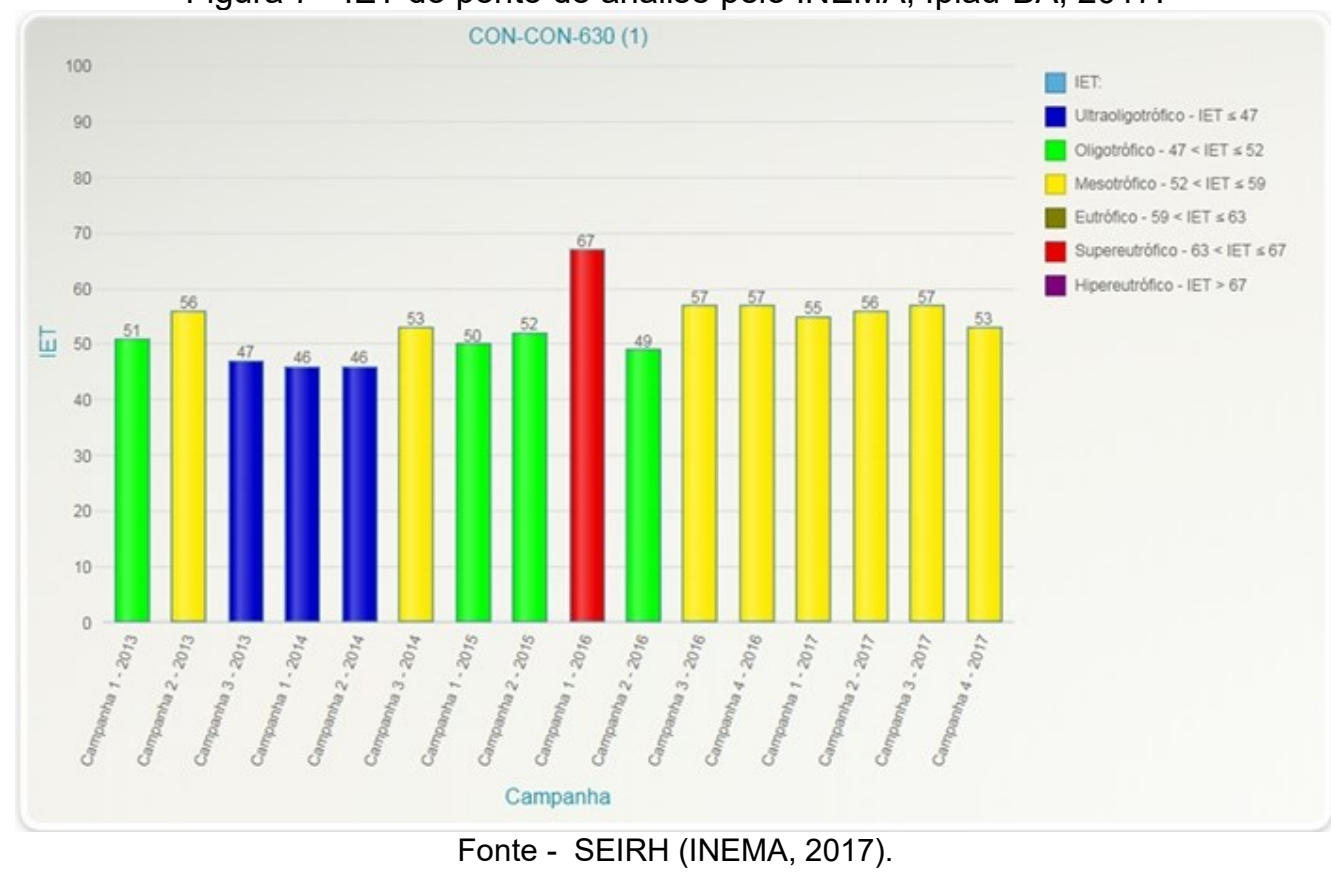

Já os valores disponíveis no site Hidroweb da SNIRH da ANA (2018) correspondem a parâmetros físicos, químicos e biológicos da qualidade de águas, coletados durante um período de aproximadamente um ano e apresentado como uma média de cada um desses indicadores (ver Tabela 2). Tais coletas foram realizadas em dois pontos de medições próximos um do outro e estão presentes no trecho final do rio de Contas, em Ipiaú.

Tabela 2 - Valores médios parâmetros de Qualidade da Água nos pontos 1 e 2 no trecho do rio de Contas em Ipiaú-BA, em análise da ANA.

\begin{tabular}{ccccccccc}
\hline & $\begin{array}{c}\text { Temperatura da } \\
\text { Amostra }\left({ }^{\circ} \mathbf{c}\right)\end{array}$ & Ph & $\begin{array}{c}\text { Turbidez } \\
(\mathbf{N T U})\end{array}$ & $\begin{array}{c}\text { DQO } \\
\left(\mathbf{m g} / \mathbf{l}^{-1}\right)\end{array}$ & $\begin{array}{c}\text { DBO } \\
\left(\mathbf{m g} / \mathbf{l}^{-1}\right)\end{array}$ & $\begin{array}{c}\text { OD } \\
\left(\mathbf{m g} / \mathbf{l}^{-1}\right)\end{array}$ & $\begin{array}{c}\text { Condutividade } \\
\text { elétrica }\end{array}$ & $\begin{array}{c}\text { Sólidos Totais } \\
\text { Dissolvidos } \\
\left(\mathbf{m g} / \mathbf{l}^{-1}\right)\end{array}$ \\
\hline Ponto 1 & 27,2 & 7,2 & 68 & 23,5 & 2 & 6,3 & 152,3 & 107 \\
Ponto 2 & 26,5 & 7,4 & 30 & - & - & 6,7 & 261,7 & - \\
\hline \multicolumn{7}{r}{ Fonte - Hidroweb da SNIRH (ANA, [2016]). }
\end{tabular}

De acordo com os dados da Tabela 2, relacionados à qualidade das águas e os pontos de análise, a ANA apresenta parâmetros de comparação. Quanto ao potencial hidrogeniônico, a Resolução CONAMA 357/2005 estabelece que para a proteção da vida aquática o pH deve estar entre 6 e 9 (BRASIL, 2005); assim, os valores dos pontos 1 e 2 de análise da ANA estão com ótimos níveis.

Quanto à turbidez da água, os valores na Tabela 2 variam pela quantidade de sólidos em suspensão (silte, areia, argila, algas, detritos, etc.). Segundo a ANA (2018), a origem desses materiais pode ser o solo (quando não há mata ciliar); a mineração (como a retirada de areia ou a exploração de argila); as indústrias; ou o esgoto doméstico, lançado no manancial sem tratamento. Assim, os valores das amostras são aceitos, pois são inferiores a 100 UNT (unidades nefelométrica de turbidez), segundo a resolução $n^{\circ} 357 / 2005$ do CONAMA, que impõe limites de turbidez de 40 UNT para águas doces classe 1 e de 100 UNT para as classes 2 e 3 (BRASIL, 2005).

O ponto 1, disposto na Tabela 2, apresenta Demanda Química de Oxigênio (DQO) dentro dos valores máximos permitidos pela resolução $n^{\circ} 357 / 2005$ do CONAMA (BRASIL, 2005). Este é um parâmetro indispensável nos estudos de caracterização de esgotos sanitários e de efluentes industriais. A DQO considera a quantidade de Oxigênio Dissolvido (OD) consumido em meio ácido que leva à degradação de matéria orgânica (VON SPERLING, 1996). 
As análises dos pontos 1 e 2 de qualidade hídrica da ANA, na Tabela 2, também apresentam dados de OD, os quais estão em enquadramentos de níveis aceitáveis na classe I da resolução n 357/2005 do CONAMA (BRASIL, 2005), conforme a temperatura da água registrada.

A condutividade elétrica corresponde à medida da facilidade com a qual a água permite a passagem de corrente elétrica. Os valores 152,3 e 261,7 dos pontos 1 e 2, respectivamente, estão dentro dos parâmetros aceitáveis para água doce não tratada, pela resolução $n^{\circ}$ 357/2005 do CONAMA (BRASIL, 2005).

Referente ao registro da qualidade de águas disponibilizado pela Embasa, cujo objetivo é analisar se o esgoto da cidade de Ipiaú, que é liberado no rio de Contas, está em situação que não comprometa a qualidade das suas águas a partir de sua descarga, têm-se os dados dispostos na Tabela 3.

É importante considerar do que se tratam estes dados dispostos na Tabela 3 e quais os valores máximos estabelecidos garantem a qualidade do rio de Contas no trecho de Ipiaú-BA, ainda não citados nesta pesquisa e que foram abordados nesta análise.

$\mathrm{Na}$ análise dos fatores físicos e químicos, os valores de pH estão todos dentro dos limites estabelecidos pela resolução 357/2005 do CONAMA, cujo $\mathrm{pH}$ varia entre 6,0 a 9,0 referentes às águas doces (BRASIL, 2005). Nos meses de julho, setembro e novembro, há um aumento em comparação aos outros meses do ano de 2017. Em julho e setembro o pH está neutro, variando em 7, enquanto no mês de novembro este valor varia em 8. Quando há a floração de algas (causada pela eutrofização ainda que incipiente) o pH tende a aumentar nos sistemas aquáticos (CETESB, 2018).

Já o material flutuante é tudo o que pode ser transportado por um rio. Nesta avaliação não há diferenciação se o material é de origem natural (como folhas e galhos) ou produtos industrializados. Acredita-se que se refere à espuma originada por detergentes provenientes de esgotos domésticos e resíduos industriais. Em todas as análises de campo realizadas pela Embasa, só foi detectada a presença de materiais flutuantes nos meses de outubro e novembro, sendo estes materiais de caráter artificial.

Ao que se refere a Sólidos Totais Dissolvidos (STD), Von Sperling (1996) define como: sais, matéria orgânica, argilas, vírus ou algumas bactérias, ou seja, tudo o que passe pelo filtro com porosidade de tamanho padronizado (o que não é sólido em suspensão é considerado solido dissolvido). O CONAMA em sua Resolução $357 / 2005$, estabeleceu como padrão de qualidade, valores máximos permitidos para STD $500 \mathrm{mg} / \mathrm{L}$ (BRASIL, 2005). Referente aos valores de STD, em nenhuma coleta foram registrados valores maiores que o estabelecido pelo CONAMA. Destacam-se os números quando comparados os pontos de montante e jusante, pois no mês de julho este parâmetro aumentou em sete vezes na jusante em relação à montante; e nos meses de setembro, outubro e novembro os valores triplicaram, aproximadamente.

Quanto a Demanda Bioquímica de Oxigênio (DBO), a ANA (2018) define como a atividade microbiana aeróbia, que oxidará a matéria orgânica presente na água através da decomposição. Ou seja, a DBO é provocada por despejos de origem predominantemente orgânica e induzem ao completo esgotamento do oxigênio na água, provocando o desaparecimento da vida aquática (CETESB, 2018). O CONAMA, na mesma resolução (BRASIL, 2005), define para as classes de águas doces: classe I DBO 5 dias a $20^{\circ} \mathrm{C}$ até $3 \mathrm{mg} / \mathrm{L}$ O2; classe II - DBO 5 dias a $20^{\circ} \mathrm{C}$ até $5 \mathrm{mg} / \mathrm{L} \mathrm{O2;} \mathrm{e} \mathrm{classe} \mathrm{III} \mathrm{-} \mathrm{DBO} 5$ dias a $20^{\circ} \mathrm{C}$ até $10 \mathrm{mg} / \mathrm{L} \mathrm{O}$. 
Tabela 3 - Dados de monitoramento ambiental em coleta realizada pela Embasa, durante o ano de 2017, nos pontos a jusante e a montante do corpo receptor no rio de Contas, no trecho de Ipiaú-BA.

\begin{tabular}{|c|c|c|c|c|c|c|c|c|c|c|}
\hline & $\begin{array}{c}\text { CORPO } \\
\text { RECEPTOR }\end{array}$ & PH & $\begin{array}{l}\text { MATERIAIS } \\
\text { FLUTUANTES }\end{array}$ & $\begin{array}{l}\text { SÓLIDOS TOTAIS } \\
\text { DISSOLVIDOS } \\
\left(\mathrm{MG} / \mathrm{L}^{-1}\right)\end{array}$ & $\begin{array}{c}\text { DBO } \\
\left(\mathrm{MG} / \mathrm{L}^{-1}\right)\end{array}$ & $\begin{array}{c}\text { DQO } \\
\left(M G / L^{-1}\right)\end{array}$ & $\begin{array}{l}\text { TEMPERATURA } \\
\left({ }^{\circ} \mathrm{C}\right)\end{array}$ & $\begin{array}{c}\text { OD } \\
\left(M G / L^{-1}\right)\end{array}$ & $\begin{array}{l}\text { COLIFORMES } \\
\text { TOTAIS (NMP) }\end{array}$ & $\begin{array}{l}\text { E. COLI } \\
\text { (NMP) }\end{array}$ \\
\hline \multirow{2}{*}{ Janeiro } & Montante & 6,55 & - & - & - & 32,8 & 27 & 4,30 & 44000 & 510 \\
\hline & Jusante & - & - & - & - & - & - & - & - & - \\
\hline \multirow{2}{*}{ Fevereiro } & Montante & 6,44 & - & - & - & 14,0 & 27 & 4,10 & 24000 & 340 \\
\hline & Jusante & 6,40 & - & - & - & 7,0 & 27 & - & 25000 & 630 \\
\hline \multirow{2}{*}{ Março } & Montante & 6,63 & - & 114,56 & - & 5,8 & 29 & 3,79 & 20000 & 52 \\
\hline & Jusante & 6,60 & - & 125,64 & - & 10,3 & 28 & 4,49 & 31000 & 310 \\
\hline \multirow{2}{*}{ Abril } & Montante & 6,82 & - & - & 9,90 & 14,5 & 28,7 & 2,89 & 16000 & 210 \\
\hline & Jusante & - & - & - & - & - & - & - & - & - \\
\hline \multirow{2}{*}{ Maio } & Montante & 6,44 & - & 99,93 & 1,30 & 9,5 & 25 & 4,36 & 52000 & 320 \\
\hline & Jusante & 6,47 & - & 87,01 & 1,80 & 5,9 & 25 & 1,42 & 110000 & 200 \\
\hline \multirow{2}{*}{ Junho } & Montante & 6,47 & - & 78,59 & 2,40 & 4,5 & 22 & 4,73 & 2000 & 158 \\
\hline & Jusante & 6,46 & - & 94,32 & 2,50 & 3,5 & 23 & 2,72 & 12000 & 310 \\
\hline \multirow{2}{*}{ Julho } & Montante & 7,39 & - & 16,00 & 1,80 & 26,0 & 22,9 & 3,83 & 46000 & 160 \\
\hline & Jusante & 7,37 & - & 123,00 & 3,50 & 70,0 & 23,2 & 0,92 & 21000 & 96 \\
\hline \multirow{2}{*}{ Agosto } & Montante & 6,41 & - & 66,05 & 5,90 & 14,0 & 22 & - & - & - \\
\hline & Jusante & 6,43 & - & 91,01 & 12,00 & 41,0 & 21 & - & - & - \\
\hline \multirow{2}{*}{ Setembro } & Montante & 7,13 & - & 38,35 & 4,40 & 11,0 & 23,4 & 4,23 & - & - \\
\hline & Jusante & 7,18 & - & 111,90 & 10,30 & 44,0 & 23 & 1,03 & - & - \\
\hline \multirow{2}{*}{ Outubro } & Montante & 6,58 & Presente & 37,33 & 6,10 & 8,0 & 27 & 4,19 & 15531 & 337 \\
\hline & Jusante & 6,55 & Presente & 68,72 & 10,10 & 31,0 & 27 & 3,01 & 61000 & 156 \\
\hline \multirow{2}{*}{ Novembro } & Montante & 8,13 & Presente & 36,10 & 1,20 & 25,0 & 27 & 2,45 & 3900 & 150 \\
\hline & Jusante & 7,96 & Presente & 94,22 & 5,20 & 47,0 & 27 & 2,12 & 39000 & 300 \\
\hline \multirow{2}{*}{ Dezembro } & Montante & 6,61 & - & 60,85 & 3,60 & 62,0 & 25 & 3,88 & 4300 & 63 \\
\hline & Jusante & - & - & - & - & - & - & - & - & - \\
\hline
\end{tabular}

Fonte - Relatório de Monitoramento Ambiental (Embasa, 2017). 
Quanto à DBO, conforme os dados da Tabela 3, no mês de abril o ponto de coleta a montante do ponto receptor apresenta valor de $9,90 \mathrm{mg} / \mathrm{L}$, o que enquadra estas águas na classe III de água doce segundo o CONAMA. Nos meses de agosto, setembro e outubro o corpo receptor a jusante, isto é, após o descarte do esgoto tratado, tem valor 12,0 mg/L, 10,3 mg/L e 10,1 $\mathrm{mg} / \mathrm{L}$,respectivamente, o que ultrapassa a classe III. Observam-se as diferenças entre valores de jusante quanto a montante nos meses de agosto, setembro, outubro e novembro, nos quais os números triplicam aproximadamente.

Os parâmetros de DQO e DBO possuem relação direta e correspondem à oxidação da matéria orgânica. As análises de DQO estão todas dentro dos limites aceitáveis na área estudada, são quase inexistentes os efluentes de origem industrial.

Conforme os valores correspondentes aos níveis de turbidez, dispostos na Tabela 3 todos os registros estão muito abaixo do limite máximo aceitável pelo CONAMA. Destacam-se os meses de julho com valores aproximadamente quatro vezes maiores na comparação montante-jusante e agosto apresentando números quase oito vezes maiores.

Nesta análise, os valores de OD variam abaixo de $5 \mathrm{mg} / \mathrm{L}^{-1}$ - característica típica de águas poluídas por esgotos. Para a EMBRAPA (2018), a descarga em excesso de material orgânico na água pode resultar no esgotamento de oxigênio do sistema. Exposições prolongadas a concentrações abaixo de $5 \mathrm{mg} / \mathrm{L}$ podem não matar alguns organismos presentes, mas aumentam a susceptibilidade ao estresse. Exposição abaixo de $2 \mathrm{mg} / \mathrm{L}$ pode levar à morte a maioria dos organismos. Destacam-se os valores de OD ( $\mathrm{mg} / \mathrm{L})$ nos meses de abril (na análise à montante), junho (os valores de relação jusante-montante diminuíram a metade), julho, agosto e setembro (o ponto à jusante do lançamento do efluente atinge valores aproximados a $1 \mathrm{mg} / \mathrm{L}$ ), e novembro (a jusante e a montante os valores estão próximos de $2 \mathrm{mg} / \mathrm{L}$ ).

No tocante aos parâmetros biológicos, as análises ofertadas pela Embasa apresentam dados de Coliformes Totais, cuja unidade de medida é o Número Mais Provável (NPM), segundo Von Sperling (1996). Esse aspecto é importante no resultado de qualidade hídrica quanto à possibilidade de transmissão de doenças. O parâmetro estabelecido pela resolução CONAMA 237/2005, estabelece valores máximos para água doce de 20.000 coliformes por $100 \mathrm{~mL}$ de água, na classe III de águas doces (BRASIL, 2005). Na análise realizada pela Embasa, na qual, os valores ultrapassam em até 5 vezes o valor máximo estabelecido como em tal classe, destacam-se os pontos a jusante e a montante nos meses de janeiro (44.000 NPM a montante), maio (52.000 NPM a montante e 100.000 NPM a jusante), outubro (61.000 NPM a jusante) e novembro (39.000 NPM a jusante, dez vezes mais que o valor a montante).

Quanto ao parâmetro de E. Coli, abundante em fezes humanas e de animais, tendo, somente sido encontrada em esgotos, efluentes, águas naturais e solos que tenham recebido contaminação fecal recente (BRASIL, 2000), os valores máximos estabelecidos pelo CONAMA em Resolução $n^{\circ} 274$ de 2000, para águas consideradas próprias para uso não podem ultrapassar 800 (neste nível, classificado como satisfatória). Conforme dados da Tabela 3, nenhuma das análises atinge o nível máximo, com destaque para o mês de fevereiro no ponto do corpo receptor a jusante do lançamento do efluente tratado (630 NMP).

\section{CONSIDERAÇÕES FINAIS}

Ipiaú desenvolveu-se primordialmente às margens do rio de Contas, com atividades de agricultura ligadas à produção de mandioca, de cacau, pecuária e a outras atividades agrossilvipastoris. Em consequência da concentração populacional surgiu o núcleo urbano. Tendo em vista o impacto de atividades antrópicas diretas e indiretas no rio de Contas, desde o desenvolvimento urbano, é essencial entender a atual situação de infraestrutura considerando o saneamento básico, quais os usos que se dão na APP do rio e qual a situação, em qualidade hídrica do mesmo.

Do exposto, com relação à infraestrutura de esgotamento sanitário, de acordo com os setores censitários analisados, os quais têm números expressivos, aproximadamente 2.064 domicílios possuem o esgoto doméstico com destino inadequado, ocorrido pelo lançamento em rios e lagos, em valas, por fossas rudimentares ou em outros destinos. Todos os setores censitários 
analisados possuem sistema de rede geral de coleta de esgoto ou pluvial, porém, em alguns este serviço é deficiente, a exemplo do setor onde se localiza parte do bairro Aloísio Conrado. A presença de fossa séptica nos domicílios - alternativa viável de tratamento de esgotos domésticos - é mínima, somando 40 domicílios nos setores censitários analisados. Nesse contexto, tendo em vista o número de domicílios (entre rural e urbano) que o município possui, mais de $15 \%$ destes (contabilizando somente a área em estudo), servem como fonte de poluição, em consideração dos esgotos domésticos, e contribuem para a alteração da qualidade da água no trecho em estudo.

Quanto ao uso e ocupação do solo na APP do rio de Contas, cuja área deveria possuir boas condições de preservação e vegetação original, como definido no novo Código Florestal (BRASIL, 2012), têm-se atividades desenvolvidas que impactam negativamente o curso fluvial. São elas: atividades agropecuárias, ocupação urbana, solo exposto, estradas pavimentadas e não pavimentadas e represas, que são usos antrópicos com consideráveis consequências. Somadas, ocupam 81,3 \% da área, enquanto as áreas úmidas e alagadas e manchas de vegetação arbórea em condições naturais contabilizam 18,7 \%.

Os dados da qualidade da água apresentados na pesquisa apontam as consequências dos usos e ocupações e da falta de saneamento adequado na área de estudo. Amostras tratadas no ponto de coleta da ANA, apesar dos valores satisfatórios de OD, mostram elevado valor de DBO, ou seja, 4 vezes superior ao aceitável pela resolução CONAMA $n^{\circ} 357 / 2005$, o que já pode identificar uma perda na qualidade da água no ponto estudado. Tal fato foi corroborado pela classe de mesotrófico indicado pelo IET calculado pelo INEMA, já que este ponto e o ponto 2 de análise da ANA estão na mesma localização.

Quanto aos dados de monitoramento ambiental e registro de qualidade ofertados pela Embasa, os valores das variáveis físicas, químicas e biológicas estão, em sua maioria, próximos dos limites máximos aceitáveis pelo CONAMA. Assim como, apresentam-se maiores nos pontos a jusante, em comparação com a análise a montante do lançamento do efluente tratado. Em alguns parâmetros, até 5 vezes maiores (como em valores de SDT, DQO, Turbidez, Coliformes Totais) ou diminuindo à metade (como em valores de $\mathrm{OD}$ ).

Dado o apresentado, faz-se necessária uma fiscalização efetiva nas APP do rio de Contas, recomendando os proprietários das terras desta área a recompor a vegetação original, com a finalidade de promover áreas ecologicamente equilibradas, em conformidade com a lei. Tendo em vista que no Art, $7^{\circ}$ do Código Florestal, em alguns pontos é autorizada a supressão de APP em áreas urbanas já consolidadas, a atenção deve ser voltada para alternativas viáveis de tratamento de efluentes domésticos e infraestrutura de saneamento básico adequada para todo o município de Ipiaú, com foco nas áreas urbanizadas. Assim como na recuperação de canais, nos quais, conforme afirma CUNHA (2003) devem se considerados aspectos hidrológicos, morfológicos e ecológicos, de qualidade da água, e estéticos, além da necessidade de uma visão integradora do projeto sustentável de recuperação.

\section{REFERÊNCIAS}

ANA - Agência Nacional de Águas. Rede Hidrometeorológica Nacional. 2005. Disponível em: <http://www.snirh.gov.br/hidroweb/publico/apresentacao.jsf>. Acesso em: 15 de setembro de 2018.

ARCOVA, F. C. S.; CICCO, V. Qualidade da água de microbacias com diferentes usos do solo na região do Cunha, Estado de São Paulo. Scientia Forestalis, Piracicaba, n. 56, p 125-134, 1999.

EMBRAPA - Empresa Brasileira de Pesquisa Agropecuária. Fossa Séptica Biodigestora. 2018. Disponível em: <https://www.embrapa.br/gado-de-leite/busca-de-solucoes-tecnologicas//produto-servico/721/fossa-septica-biodigestora>. Acesso em: 12 de outubro de 2018.

Oxigênio Dissolvido. 2018.2 Disponível em: <http://www.cnpma.embrapa.br/projetos/ecoagua/eco/oxigdiss.html>. Acesso em: $22 \mathrm{de}$ setembro de 2018. 
BRASIL. Conselho Nacional de Meio Ambiente (CONAMA), Resolução n. 274, de 29 de novembro de 2000.2 Disponível em: <http://pnqa.ana.gov.br/Publicacao/Resolu\%C3\%A7\%C3\%A3o_Conama_274_Balneabilidade.p df>. Acesso em: 4 de setembro de 2018.

Conselho Nacional de Meio Ambiente (CONAMA), Resolução n. 357, de 17 de março de 2005. Disponível em: <http://www.mma.gov.br/port/conama/res/res05/res35705.pdf>. Acesso em: 4 de janeiro de 2018.

Lei $\mathrm{n}^{\circ}$ 12.651, de 25 de maio de 2012. Disponível em: <http://www.planalto.gov.br/ccivil_03/_Ato2011- 2014/2012/Lei/L12651.htm>. Acesso: 4 de janeiro de 2018.

CETESB - Companhia Ambiental do Estado de São Paulo. Mortandade de peixes. 2018. Disponível em: <https://cetesb.sp.gov.br/mortandade-peixes/alteracoes-fisicas-e-quimicas/ph/>. Acesso em: 15 de setembro de 2018.

FRANÇA, C. J. de et al. Compatibilização dos bairros e unidades de planejamento com os setores censitários no estado o Espírito Santo. Geografares, Vitória, v. 6, p. 35-46, 2008. Disponível em: <http://www.portaldepublicacoes.ufes.br/geografares/article/download/1014/749>. Acesso em: 24 de março de 2018.

FINKLER, R. Planejamento, manejo e gestão de bacias: unidade 1 - A Bacia Hidrográfica. Disponível em: <https://capacitacao.ead.unesp.br/dspace/bitstream/ana/82/2/Unidade_1.pdf>. Acesso em: 30 de dezembro de 2017.

GÜNTHER, H. Pesquisa qualitativa versus pesquisa quantitativa: esta é a questão. Psicologia: teoria e pesquisa, Brasília, v. 22, n. 2, p. 201-210, 2006. Disponível em: <http://www.scielo.br/pdf/ptp/v22n2/a10v22n2>. Acesso em: 15 de outubro de 2018. https://doi.org/10.1590/S0102-37722006000200010

IBGE - Instituto Brasileiro de Geografia e Estatística. Manual técnico de uso da terra. IBGE, 2006. Disponível em: <https://biblioteca.ibge.gov.br/visualizacao/livros/liv81615.pdf>. Acesso em: 22 de junho de 2018.

setembro de 2018.

Censo 2010. Disponível em:<https://censo2010.ibge.gov.br>. Acesso em: 15 de

INEMA - Instituto do Meio Ambiente e Recursos Hídricos. Monitoramento. 2017. Disponível em: < http://monitoramento.seia.ba.gov.br/>. Acesso em: 15 de setembro de 2018.

Caracterização da CBH rio de Contas. 2018. Disponível em: <http://www.inema ba.gov.br/gestao2/comites-de-bacias/comites/cbh-contas/>. Acesso em: 25 de agosto de 2018.

MERTEA, G. H.; MINELLA, J. P. Qualidade da água em bacias hidrográficas rurais: um desafio atual para a sobrevivência futura. Agroecologia e Desenvolvimento Rural Sustentável, Porto Alegre , v. 3 , n. 4, p. 33-38, 2002. Disponível em: $<$ http://taquari.emater.tche.br/docs/agroeco/revista/ano3_n4/artigo2.pdf>. Acesso em: 7 de novembro de 2017.

PINHO, A. G. Estudo da qualidade das águas do rio Cachoeira - Região Sul da Bahia. Dissertação (Mestrado em Desenvolvimento Regional e Meio Ambiente) - Ilhéus: UESC. 2001.

SANTOS, K. A.; RUFINO, I. A. A.; BARROS FILHO, M. N. M. Impactos da permeabilidade do solo: o caso de uma área de urbanização consolidada em Campina Grande-PB. Engenharia Sanitária e Ambiental, rio de Janeiro, v. 22, n. 5, 2017. Disponível em: < http://submission.scielo.br/index.php/esa/article/view/146661>. Acesso em: 5 de setembro de 2018. https://doi.org/10.1590/s1413-41522016146661

SEIA-BA. Sistema Estadual de Informações Ambientais e Recursos Hídricos. Monitoramento ambiental. 2018. Disponível em: <http://www.seia.ba.gov.br/monitoramentoambiental/qualidade-das-guas>. Acesso em: 4 de janeiro de 2018. 
TRINDADE, G. A. Aglomeração Itabuna - Ilhéus: cidade, região e rede urbana. Tese (Doutorado em Geografia) - São Cristóvão: UFS. 2011. Disponível em: <https://ri.ufs.br/handle/riufs/5438>. Acesso em: 18 de outubro de 2017.

TUCCI, C. E. M; SILVEIRA, A. Gerenciamento da drenagem urbana. Revista Brasileira de Recursos Hídricos, Porto Alegre, v. 7, n. 1, jan./mar. 2002, p. 5-27, 2001. Disponível em: <http://rhama.com.br/blog/wp-content/uploads/2017/01/GEREN02.pdf>. Acesso em: 5 de novembro de 2017. https://doi.org/10.21168/rbrh.v7n1.p5-27

VALENTE, J. P. S.; PADILHA, P. M.; SILVA, A. M. M. Oxigênio Dissolvido (OD) Demanda Bioquímica de Oxigênio (DBO) e Demanda Química de Oxigênio (DQO) como parâmetros de poluição no ribeirão Lavapés/Botucatu-SP. Eclética Química, Sáo Paulo, v. 22, p. 49-66, 1997. Disponível em: <https://repositorio.unesp.br/handle/11449/27643>. Acesso em: 14 de outubro de 2018. https://doi.org/10.1590/S0100-46701997000100005

VON SPERLING, M. Introdução à qualidade das águas e ao tratamento de esgotos. 2. ed. Belo Horizonte: Editora UFMG, 1996. 452 p.

Recebido em: 16/05/2019

Aceito para publicação em: 24/10/2019 